\title{
PENGAMBILAN KEPUTUSAN ORANG TUA DALAM \\ MENGGUNAKAN POLA ASUH ANAK
}

\section{Nuraini Sihite}

\section{Email: Nurainisihite4@gmail.com}

\section{LATAR BELAKANG:}

keluarga merupakan lingkungan pertama kali yang memberikan pendidikan kepada anak, karena lingkungan dalam suatu keluarga yang akan mempengarahui sikap, karakter, serta tumbuh kembang anak.selain itu didalam keluarga orang tua memiliki peran besar dalam memberikan pengaruh pada perkembangan sosial anak.

Setiap orang tua tentu mempunyai pola asuh yang berbeda. Selain itu pengambilan keputusan oleh orang tua dalam menggunakan pola asuh anak juga merupakan suatu proses dimana orang tua akan mendidik, mengarahkan dan membimbing anak dalam membentuk kepribadian, untuk mencapai masa kedewasaan yang sesuai dan mendapatkan perkembangan sosial yang baik. Perkembangan sosial yang baik itu akan menuntun anak dalam lingkungan sosialnya, kepribadian yang baik, dan akan menumbuhkan rasa percaya diri ketika akan bersosialisasi dengan lingkungan.

Terdapat tiga macam pola asuh yang dapat diterapkan orang tua kepada anak, yaitu : pola asuh demokratis, permisif dan otoritas. Pola asuh demokratis memberikan kebebasan kepada anak dengan penuh tanggung jawab, sedangkan Pola asuh otoriter merupakan cara mendidik anak dengan menggunakan kepemimpinan otoriter, yaitu orang tua menentukan semua kebijakan, langkah dan tugas yang harus dijalankan. Pola asuh otoriter mencerminkan sikap orang tua yang bertindak keras dan cenderung diskriminatif . Pola asuh permisif mempunyai ciri orang tua memberikan kebebasan penuh pada anak untuk berbuat sehingga terkadang anak melakukan tindakan yang melawan aturan. Dalam memberikan pengasuhan kepada anak dibutuhkan beberapa strategi memberikan pendidikan dengan metode keteladanan, pembiasaaan, perhatian, nasehat dan metode hukuman.

Di antara ketiga itu, pola pengasuhan otoriterlah yang dampaknya sangat berisiko bagi anak. Karena pola asuh otoriter cenderung menetapkan standar yang mutlak harus dituruti, biasanya dibarengi dengan ancaman-ancaman. Seperti anak harus mematuhi peraturanperaturan orangtua dan tidak boleh membantah, orangtua cenderung mencari kesalahan- 
kesalahan anak dan kemudian menghukumnya, atau jika terdapat perbedaan pendapat antara orangtua dan anak maka anak dianggap pembangkang. 2

Pola asuh otoriter cenderung tidak memikirkan apa yang akan terjadi di masa kemudian hari, fokusnya lebih masa kini. Orang tua mengendalikan anak lebih karena kepentingan orang tua untuk memudahkan pengasuhan. Mereka menilai dan menuntut anak untuk mematuhi standar mutlak yang ditentukan sepihak oleh orang tua. Orang tua sering tidak menyadari bahwa dikemudian hari anak-anaknya dengan pola pengasuhan otoriter mungkin akan menimbulkan masalah yang lebih rumit, meskipun anak-anak dengan pola pengasuhan otoriter ini memiliki kompetensi dan tanggung jawab cukupan, namun kebanyakan cenderung menarik diri secara sosial, kurang spontan dan tampak kurang percaya diri.

\section{METODE:}

Metode yang digunakan dalam penulisan adalah studi literatur, yang mengunakan data-data melalui jurnal- jurnal, e-book, dari situs internet yang terkait dan berhubungan dengan penulisan saya terhadap pengambilan keputusan orang tua dalam mengunakan pola asuh terhadap anak.

Adapun jurnal yang saya gunakan dalam penulisan ini adalah kumpulan jurnal-jurnal dalam kurun waktu diatas tahun 2012 dengan mengambil referensi terkait dengan pengambilan keputusan orang tua dalam menggunakan pola asuh terhadap anak.

\section{HASIL:}

Hasil yang diperoleh dari studi literatur yang dilakukan adalah keluarga merupakan lingkungan pertama kali yang memberikan pendidikan kepada anak, karena lingkungan dalam suatu keluarga yang akan mempengarahui sikap, karakter, serta tumbuh kembang anak.

Keluarga juga merupakan lingkup kehidupan yang paling berpengaruh terhadap perjalanan seorang individu serta dalam membimbing anak dalam setiap proses pengambilan keputusan, karena anak senantiasa bergantung pada ciri yangmelekat pada keluarga. Pengasuhan yang baik menimbulkan persepsi yang baik pada diri anak. Persepsi yang baik akan memudahkan dalam mengambil suatu keputusan yang hangat antara orang tua dan anak. 
Proses pengambilan keputusan dilakukan setiap hari oleh semua orang. Hubungan orang tuaanak dalam keluarga terjalin melalui interaksi komunikasi yang mereka lakukan sehari-hari.

Dalam proses pengasuhan anak, setiap orang tua memiliki pola asuh yang berbeda. Terdapat tiga macam pola asuh yang digunakan oleh orang tua dalam memberikan pengasuhan pada anak. Pola asuh pertama adalah pola asuh otoriter. Pola asuh ini mencerminkan sikap orang tua yang bertindak keras dan cenderung diskriminatif. Hal ini ditandai dengan tekanan anak untuk patuh kepada semua perintah dan keinginan orang tua, kontrol yang sangat ketat terhadap tingkah laku anak, anak kurang mendapatkan kepercayaan dari orang tua, anak sering di hukum, apabila anak mendapat prestasi jarang diberi pujian atau hadiah.

Pola asuh kedua yaitu pola asuh demokratis, pola asuh ini terdapat adanya pengakuan orang tua terhadap kemampuan anak, anak diberi kesempatan untuk tidak selalu tergantung. Pola asuh ini mendidik dan memberikan kebebasan yang bertanggung jawab pada anak. Dengan memiliki kebebasan yang bertanggung jawab, anak akan mampu mengembangkan potensi yang dimilikinya dengan baik. pola asuh yang ketiga adalah pola asuh permissif. Pola asuh permisif membiarkan anak bertindak sesuai dengan keinginannya, orang tua tidak memberikan hukuman dan pengendalian. Pola asuh ini ditandai dengan adanya kebebasan tanpa batas pada anak untuk berperilaku sesuai dengan keinginannya sendiri, orang tua tidak pernah memberikan aturan dan pengarahan kepada anak, sehingga anak akan berperilaku sesuai dengan keinginannya sendiri.

Anak yang dididik secara demokratis juga akan mempunyai kepercayaan diri yang besar, mempunyai pengertian yang benar tentang apa yang menjadi hak mereka, dapat mengkomunikasikan segala keinginannya secara wajar, dan tidak memaksakan kehendak mereka dengan menindas hak-hak orang lain.

Kepercayaan diri seseorang tidak hanya dipengaruhi oleh pola asuh orang tua, namun dapat terbentuk karena banyak faktor yang bisa melatar belakangi hal tersebut, contohnya penampilan fisik, tingkat pendidikan, lingkungan sekitar atau teman sebaya, dan lain sebagainya. Faktor-faktor tersebut pula yag dapat menjadi penyebab anak dengan pola asuh otoriter atau permisif tetap memiliki kepercayaan diri yang tinggi. 


\section{PEMBAHASAN:}

Pola asuh orang tua mempunyai peranan terhadap perkembangan anak. Ravik Karsidi (2008) menyatakan bahwa keluarga merupakan lingkup kehidupan yang paling berpengaruh terhadap perjalanan seorang individu serta dalam membimbing anak dalam setiap proses pengambilan keputusan, karena anak senantiasa bergantung pada ciri yangmelekat pada keluarga. Pengasuhan yang baik menimbulkan persepsi yang baik pada diri anak. Persepsi yang baik akan memudahkan dalam mengambil suatu keputusan yang hangat antara orang tua dan anak.

Keterbukaan diperlukan antara orang tua dan anak agar kedua belah pihak saling mengerti satu sama lain. Orang tua menyayangi dan mengasihi serta anak yang patuh dan hormat kepada orang tua. Orang tua dan anak yang harmonis akan membuat semua pihak mengerti dengan hak dan kewajiban masing-masing.

Setiap hari orangtua dan anak terlibat dalam interaksi komunikasi, secara langsung maupun melalui media. Mereka saling mempertukarkan pesan atau menyampaikan ide, gagasan, dan pendapatnya. Day (2003:17) mengungkapkan bahwa komunikasi merupakan inti dari proses ekspresif dalam keluarga dan faktor penting dalam menjalin sebuah hubungan. Tiap anggota keluarga dapat mengekspresikan pendapatnya dengan berkomunikasi satu sama lain sehingga pesan diketahui, dipahami, dan dapat direspon. Informan orangtua dan anak biasanya mengkomunikasikan secara langsung tentang kegiatan yang mereka lakukan sepanjang hari. Namun, ada informan ayah yang berkomunikasi melalui media (handphone) dengan keluarganya karena harus bekerja di luar kota.

Proses pengambilan keputusan dilakukan setiap hari oleh semua orang. Hubungan orang tua-anak dalam keluarga terjalin melalui interaksi komunikasi yang mereka lakukan sehari-hari. Pola asuh dapat didefinisikan sebagai pola interaksi antara anak dan orang tua yang meliputi pemenuhan kebutuhan fisik (seperti makan, dan minum) dan kebutuhan psikologis (seperti rasa aman, dan kasih sayang) peserta sosialisasi norma-norma yang berlaku di masyarakat agar anak dapat hidup selaras dengan lingkungannya. Dengan kata lain, pola asuh juga meliputi interaksi orang tua dengan anak dalam rangka pendidikan karakter anak, sehingga melalui pola asuh yang dilakukan oleh orang tua, anak belajar tentang banyak hal. Dalam hal ini, dapat diketahui betapa pentingnya pengaruh pola asuh orang tua terhadap keberhasilan anak. Qurrotu ayun (2017) 
Dalam mendidik anak, terdapat berbagai macam bentuk pola asuh yang biasa digunakan oleh orang tua. Hendri (2019) Pola asuh orang tua dapat didefinisikan sebagai suatu keseluruhan interaksi yang dilakukan oleh orang tua dengan anak, di mana orang tua bermaksud membimbing, menstimulasi tingkah laku, pengetahuan serta nilai-nilai yang dianggap paling tepat oleh orang tua menuju terbentuknya kepribadian yang utama, agar anak dapat mandiri, tumbuh dan berkembang secara sehat dan optimal.

Bentuk-bentuk pola asuh orang tua mempengaruhi pembentukan kepribadian anak setelah ia menjadi dewasa. Hal ini dikarenakan ciri-ciri dan unsur-unsur watak seorang individu dewasa sebenarnya jauh sebelumnya benih-benihnya sudah ditanam tumbuhkan kedalam jiwa seorang individu sejak awal, yaitu pada masa ia masih kanak-kanak. Artinya, perlakuan orang tua kepada anak-anak nya sejak masa kecil akan berdampak pada perkembangan sosial moralnya dimasa dewasa nya. Perkembangan sosial moral inilah yang akan membentuk watak sifat dan sikap anak kelak meskipun ada beberapa faktor lain yang berpengaruh dalam pembentukan sikap anak yang tercermin dalam karakter yang dimiliki nya.

Terdapat tiga macam pola asuh yang dapat diterapkan orang tua kepada anak, yaitu : pola asuh demokratis, permisif dan otoritas.

\section{a. Pola Asuh Demokratis}

Pola asuh demokratis ditandai dengan adanya pengakuan orang tua terhadap kemampuan anak ,anak diberi kesempatan untuk tidak selalu tergantung kepada orang tua. Sedikit memberi kebebasan kepada anak untuk memilih apa yang terbaik bagi dirinya,anak didengarkan pendapatnya, dilibatkan dalam pembicaraan terutamayang menyangkut dengan kehidupan anak itu sendiri.Anak diberi kesempatan untuk mengembangkan kontrol internal nya sehingga asedikit demi sedikit berlatih untuk bertanggung jawab kepada diri sendiri.

\section{b. Pola Asuh Permisif}

Pola asuh permisif adalah membiarkan anak anak bertindak sesuai dengan keinginannya, oran tua tidak memberikan hukuman dan pengendalian. Pola asuh ini ditandai dengan adanya kebebesan tanpa batas pada anak untuk berperilaku sesuai dengan keinginannya sendiri, orang tua tidak pernah memberikan aturan sesuai dengan keinginanya sendiri walaupun terkadang bertentangan dengan norma sosial. 


\section{c. Pola Asuh Otoritas}

Pola asuh otoriter merupakan cara mendidik anak dengan menggunakan kepemimpinan otoriter, kepemimpinan otoriter yaitu pemimpin menentukan semua kebijakan, langkah dan tugas yang harus dijalankan. Sebagaimana diketahui pola asuh otoriter mencerminkan sikap orang tua yang bertindak keras dan cenderung diskriminatif. Hal ini ditandai dengan tekanan anak untuk patuh kepada semua perintah dan keinginan orang tua, kontrol yang sangat ketat terhadap tingkah laku anak, anak kurang mendapatkan kepercayaan dari orang tua, anak sering di hukum, apabila anak mendapat prestasi jarang diberi pujian atau hadiah. Baumrind menjelaskan bahwa pola asuh orang tua yang otoriter ditandai dalam hubungan orang tua dengan anak tidak hangat dan sering menghukum. Pola asuh otoriter adalah pola asuh yang ditandai dengan cara mengasuh anak-anak dengan aturan yang ketat, sering kali memaksa anak untuk berperilaku seperti dirinya (orang tua), kebebasan untuk bertindak atas nama diri sendiri dibatasi, anak jarang diajak berkomunikasi dan diajak ngobrol, bercerita, bertukar pikiran dengan orang tua.

Pola asuh orang tua otoriter dan permisif yang diterapkan oleh orang tua salah satunya didasari pada pandangan yang berbeda-beda dari setiap orang tua kepada anak mereka.

Pola asuh demokratik yang diterapkan orang tua kepada anak akan memberikan wawasan berfikir, bertindak dan bersosialisasi yang baik sehingga memacu perkembangan sosial remaja untuk menjadi percaya diri. Saling keterbukaan antara anak dan orang tua merupakan salah satu dorongan anak untuk bisa mengendalikan dirinya, memberikan kesempatan remaja untuk mengeluarkan pendapatnya yakni langkah yang baik untuk menghindari remaja dari tindakan-tindakan yang negatif dan memberikan rasa percaya diri yang baik pula bagi bagi remaja.

Anak yang dididik secara demokratis juga akan mempunyai kepercayaan diri yang besar, mempunyai pengertian yang benar tentang apa yang menjadi hak mereka, dapat mengkomunikasikan segala keinginannya secara wajar, dan tidak memaksakan kehendak mereka dengan menindas hak-hak orang lain. Kekeliruan pola asuh yang diterapkan orang tua pada anaknya akan mengakibatkan terhambatnya proses perkembangan mental anak, seperti rasa percaya diri yang rendah. 
Kepercayaan diri seseorang tidak hanya dipengaruhi oleh pola asuh orang tua, namun dapat terbentuk karena banyak faktor yang bisa melatar belakangi hal tersebut, contohnya penampilan fisik, tingkat pendidikan, lingkungan sekitar atau teman sebaya, dan lain sebagainya. Faktor-faktor tersebut pula yag dapat menjadi penyebab anak dengan pola asuh otoriter atau permisif tetap memiliki kepercayaan diri yang tinggi.

\section{PENUTUP}

keluarga merupakan lingkungan pertama kali yang memberikan pendidikan kepada anak, karena lingkungan dalam suatu keluarga yang akan mempengarahui sikap, karakter, serta tumbuh kembang anak.

Pola asuh yang tepat (positif) yang diterapkan oleh orang tua dapat membentuk konsep diri yang positif pada anak. Sebaliknya, pola asuh yang tidak tepat (tidak positif) sering memberi stigma dan label negatif kepada anak akan menjadi dasar terbentuknya konsep diri yang negative pada anak. pola asuh orang tua terbagi menjadi 3 yaitu pola asuh otoriter (Authoritarian), pola asuh demokratis (Democratie), dan pola asuh permisif (Permissive). Dari ketiga jenis pola asuh yang diterapkan oleh orang tuamemiliki kekurangan dan kelebihan serta dampak nya masing-masing bagi perkembangan emosional anak.

\section{DAFTAR PUSTAKA}

Simamora, R. H. (2019). Menjadiperawat yang: ClH'HUY. Surakarta: Kekata Publisher.

Simamora,

$\mathrm{R}$.

$\mathrm{H}$. (2005). HubunganPersepsiPerawatPelaksanaTerhadapPenerapanFungsiPengorganisasian Yang DilakukanOlehKepalaRuanganDenganKinerjanyaDiruangRawatInap RSUD Koja Jakarta Utara (Doctoral dissertation, Tesis FIK UI, Tidakdipublikasikan).

Ayun Qurrotu. 2017. Pola asuh orang tua dan metode pengasuhan dalam membentuk kepribadian anak. Vol 5 No 1.

Pertiwi Endang, dkk. 2016. Hubungan pola asuh orang tua dengan perkembangan sosial (percaya diri)remaja di SMA negeri 7 Manado. e-journal keperawatan (e-kp) Volume 4 No 2.

Popy Puspita Sari, dkk. 2020. Pola asuh orang tua terhadap perkembangan emosional anak usia dini. Jurnal PAUD Agapedia, Vol.4 No 1.

Ravik, Karsidi. 2008. Sosiologi Pendidikan. Surakarta: LPP UNS dan UNS Press. 
Afrilyanti, dkk. 2015. Hubungan pola asuh orang tua dengan status identitas diri remaja. JOM Vol 2 No 2.

Rini Susetyo Yohana. 2014. Komunikasi orang tua-anak dalam pengambilan keputusan pendidikan. JURNAL INTERAKSI Vol 3 No 2.

Zubaedi. 2011. Desain pendidikan karakter konsep dan aplikasinya nya dalam lembaga pendidikan. Jakarta: kencana

Hendri. 2019. Peran pola asuh orang tua terhadap pembentukan konsep diri pada anak. Jurnal At-Taujih bimbingan dan konseling islam Vol. 2 No. 2.

Shafrila. 2019. Hubungan antara pola asuh otoriter dengan pengambilan keputusan karier pada siswa smk teuku umar semarang. Jurnal empati, Volume 8 No 1.

Sureti Melinda, dkk. 2019. Pengaruh pola asuh orag tua terhadap kemampuan pengambilan keputusan mahasiswa etnis sumba di salatiga. Jurnal psikologi konseling Vol.14 No 1. 